\title{
Reconciliation in the General Epistles? ${ }^{1}$
}

\author{
G J Steyn \\ (University of Pretoria)
}

\section{ABSTRACT}

\section{Reconciliation in the General Epistles?}

Although the customary technical terms for reconciliation are not to be found frequently and explicitly in the General Epistles, the concept or motif is certainly not absent at all. The following contribution investigates the theological dimensions of this motif by using the striking image of a spiritual house, or temple, of which the believers are seen as bricks being built into the walls (1 Pet 2:4-10). Reconcilation takes shape on Christ as the cornerstone (1 Peter) with vertical pillars representing a restored relationship between God and humanity (Hebrews). This enables the horizontal dimension of the building to take shape too. In light of the restored relationship between God and humanity, a restored relationship amongst people ought to become a reality. Certain expectations (James), consequenses (1 Peter), dangers and purposes (2 Peter and Jude) facing Christians who find themselves within a reconciled relationship with God are forming the framework for reconciliation with each other.

"Forgiveness is a catalyst creating the atmosphere necessary for a fresh start and a new beginning"

(Martin Luther King).

\section{DESIGN FOR A RECONCILIATION PROCESS}

Reconciliation language refers to broken relationships that are restored (Green et al 1992:543). The technical terms that are usually employed elsewhere in the New Testament for reconciliation are virtually absent in the General Epistles (See, for instance Seifred 2004:299-310;

1 For our purposes here: The book of Hebrews and the letters of James, $1^{\text {st }}$ and $2{ }^{\text {nd }}$ Peter and Jude. Hebrews is not a letter, but rather a sermon. The Johannine Epistles are usually taken to be part of the General Epistles, but are excluded here as they are being dealt with elsewhere in this project as part of the Johannine Literature. 
M'Caig 1930:2536-2538). It is no wonder, therefore, that the contribution that those documents could have made to our understanding of reconciliation (specifically from a biblical point of view), were largely neglected in the past. Usually in thematic investigations of ancient texts is it customary to search for particular terminology and then to use these terms, words or phrases to construct the outline of the theme under investigation. As linguists became more aware of the fact that words do not carry meaning in themselves, but that we rather use words as representative symbols to express aspects of a larger semantic field of meaning, the quest for meaning in texts reached another level. This is particularly true for the collection of books that will be dealt with in this contribution. Although the customary technical terms as such are not to be found frequently and explicitly, the concept or motif of reconciliation is certainly not absent at all in these books.

Looking anew at the process of reconciliation through the lenses of the arts, it is interesting to see how different images ${ }^{2}$ or metaphors are being employed in our collection (Hebrews, James, $1^{\text {st }}$ and $2^{\text {nd }}$ Peter, Jude) at different points in order to convey the relationship between God and humanity, on the one hand, and the relationship between human and human, on the other hand. One of the most striking images is that of a spiritual house, or temple, of which the believers are seen as the bricks that are being built into the walls (1 Pet 2:4-10). Expanding on this image of a new spiritual house within the theological parameters of our collection of books, the dimensions of such a building are taking shape. The design itself is found in the Bible - also in the so-called General Epistles. The construction site of Christian reconciliation is clearly identifiable.

- The site or field on which this building stands is that of reconciliation.

2 Cf. Tuckett (1996:518): “One notable feature of NT ideas about the atonement is their variety. Not only are differences found between NT writers but even the same writer can use what appears at times to be a bewildering variety of models and images to describe how the life, death, and resurrection of Jesus have changed the human situation”. 
- The cornerstone of the building forms the orientation point from where the building lines are going out and is thus the mediatory point between the vertical and horizontal dimensions. It stands as the exemplary stone for all the others that are being built into the walls. It forms the focal point and holds the building together. Christ is compared with the cornerstone.

- The vertical pillars represent the reconciled relationship between God and humanity.

- The horizontal beams and rows of bricks represent the relationship between humans. The image assumes a closely knitted network of believers, who are finding themselves in an interlocking framework of harmony and peace.

- A door opening represents inclusiveness and space for others to enter.

\section{CLEARING THE FIELD FOR A NEW BUILDING}

A number of words which relate to, or have a connection with reconciliation, are to be found on the building site of this term. Some of these express a passive but positive attitude that create an atmosphere conducive for reconciliation, such as tolerance, grace and christian love. Others express an active action, such as atonement, propritiation, forgiveness, redemption (cf. Heb 9:15; 11:35), salvation, justification and sanctification. Others again, such as restoration, reunion and peace are pointing to the result of the process, or the state in which the different parties find themselves after reconciliation.

Apart from an occurrence of the term in Hebrews 2:17 (not with the proper meaning 'reconciliation' - so also Walvoord 1962:293-294) and a related term in Hebrews 9:5 (which refers to the lid of the ark of the covenant in the Old Testament), it was already stated that the technical terms as such for reconciliation do not appear in Hebrews, James, 1 \& 2 Peter and Jude. Looking, however, at the process of reconciliation and related aspects as described above, there is no doubt that these New Testament books can contribute significantly to our understanding of reconciliation. 


\section{Laying the cornerstone - an image from 1 Peter}

1 Peter 2 explains on the basis of Isaiah 28:16 how Jesus Christ is the cornerstone who holds an honorary position. The position of the cornerstone ultimately forms the orientation point for the framework of reconciliation. It is the focal point of the new building that arises from the field. This cornerstone is identified with Jesus Christ himself. In this sense the cornerstone becomes examplary for the rest of the building blocks. It becomes the ultimate Role Model that ought to be imitated as brick after brick and layer after layer are being built onto and being put into place in the process of erecting a new temple. Christian believers are compared with these living stones that ought to be built into a spiritual house (1 Pt 2:5). Those who believe share thus in this honorary position (1 Pt 2:7).

A number of scholars pointed out that the idea of someone (a person) who dies for another was fairly widespread in Greek thinking (Williams 1975; Hengel 1981; Tuckett 1996), but rare amongst the Jewish people. The mediatory aspect of Christ's death on the cross is explicitly described in 1 Peter 2:24.

\section{DIMENSIONS}

\subsection{The vertical dimension - according to Hebrews}

The framework within which the new spiritual house rises up from the ground and from its foundational cornerstone, requires a number of strong vertical pillars. In order to both withstand the pulling force of gravity and to carry and support the weight of the stones, these vertical pillars are crucial in the structure of the new building. They have to be stronger and harder than any stone. These vertical pillars are representative of the vertical relationship between God and humanity. Only after the cornerstone or foundation has been put in place, in other words, only after the place which Christ has taken, can the vertical pillar be firmly put in place. It is on this solid basis of the foundational stone that the building finds its future existence.

Particularly the book of Hebrews presents the image of this vertical relationship between God and humanity. This damaged and broken relationship of an old order, of an old covenant that was breached, is now repaired. If that old covenantal relationship was in 
order, then there would not have been a need for a new covenant (Heb 8:7). Christian believers find themselves within a new covenantal relationship with God. This is an idea that the unknown author of Hebrews explains on the basis of the longest quotation in the New Testament, that of Jeremiah 31:31-34.

Within the old covenantal relationship any transgression implied disobedience and disobedience meant a breach of the contractual relationship between God and his people. Punishment for this was death. There was only one way in which that relationship could be rectified. Another life should be given on behalf of the transgressor. By means of sacrifices and the shedding of animal blood on behalf of individuals and on behalf of the people of God corporately, atonement for sins could take place. This was the requirement by the Old Testament law for forgiveness of sin to take place. This particular aspect is persued by Hebrews: "Without the shedding of blood there is no forgiveness" (Heb 9:22). Refer, for instance, also to the motif of the pascha as presented in Hebrews 11:28. Forgiveness by God could then follow because of the punishment of a mediatory subject. It could thus even be stated that reconciliation is expressed as forgiveness in Hebrews. Priests played a key role in this cultic process of mediation by accepting animals to be sacrificed for God.

This cultic motif is strongly taken up in both Hebrews and in 1 Peter 1:19. Christ is pictured in Hebrews $4-10$ as being the High Priest who brings this sacrifice to temple. But there are some striking differences too with the old covenantal situation. Not only is Christ the priest who brings this sacrifice (Heb 2:17), he is simultaneously the sacrifice himself (Heb 9:14)! Jesus' death is thus interpreted in a new light. He is both the priest bringing the sacrifice of atonement to God as well as being the sacrifice himself (Heb 10:11-12). He became the Mediator (similarly also in 1 Pt 2:24 - see Tuckett 1996) of a new and better covenant which thus makes him a high priest of the new covenantal relationship (Heb 7:22; 8:6; 9:15; 12:24). By being the sinless one (Heb 7:26) who is sacrificed himself, this act became a once-and-for-all sacrifice (Heb 7:27; 9:26; 10:18) (see also Seifrid 2004:301; Seume 1942:472). This leads to God's forgiveness, and 
where sin is forgiven there exists no more need for sacrifices (Heb 10:18).

The author of Hebrews pictures the uniqueness of the mediator, Christ, in different ways. There are five specific relationships in which Christ's uniqueness becomes clear.

a. The first is his relationship with God himself. In the opening argument of his document, Hebrews presents a pre-existent and exalted Christ, the 'Son' (Harrison 1964:334) through whom the world was made and who is the inheritor of all that exists. He is the exact representation of God and radiates the glory of God (Heb 1:14). He is crowned with honor and glory due to his suffering and death (Heb 2:9). (The motif of Jesus' death as a sacrifice for sins has extensively influenced the New Testament theology. See Tuckett 1996).

b. In relation to the heavenly beings, the angels, Christ is described as being superior (Heb 1:5-14). (Compare Steyn 2003:1107-1128).

c. In relation to the Old Testament 'saviour' of God's people in Egypt and as the representative of the law, Christ is pictured as being greater than Moses himself (Heb 3).

d. The same applies also to the Levitical priesthood, the cultic life and the temple. Christ is also greater than these and is high priest according to another order, one which is closest to that of Melchizedek (Heb 7). (See Steyn 2002:207-223).

e. In relation to humanity, it was God's intention to lead many to salvation as his children (Heb 2:10-18). He, therefore, became one of them (us) in all senses in order to reconcile the transgressions of his people with God (Heb 2:17). According to some scholars, the Greek word used here in Hebrews 2:17 which is usually translated with 'reconciliation', is not properly related to the doctrine of reconciliation and might rather be translated as 'propritiation', or at the most with 'atonement'. It expresses an aspect of taking away the wrath of God. Christ's relationship with humanity is one in which they are called 'children' and 'brothers' (intended also 'sisters') (Heb 2:11-13,17). 
An interesting pattern unfolds for erecting the vertical pillars of a previously broken relationship with God. Two parties were involved initially until the break in their relationship. During the process of reconciliation a third party is introduced - that of the mediator. The situation unfolded as follows: Something went wrong in the past regarding a very special covenantal relationship between God and humanity. Where sacrifices and blood of animals were repeatedly required in the past, the mediator, Christ, came once and for all (Heb $7: 27 ; 10: 18)$. God took the initiative in the process of reconciliation (Tuckett 1996), although it was not God who was responsible for this broken relationship. The innocent party in this damaged relationship took the first step here. The active step of acting in repairing the broken relationship and initiating reconcilation is taken by God as the Subject in this process. This was done by means of a mediator - Jesus Christ. He became the mediator of a new covenant. This is a deed and a gift of grace. Forgiveness by God followed for those who accepted this act boldly in faith. This is the result of God's mercy (Heb 8:12 - a quote from Jer 31:34). Expanding on the virtues of faith in Hebrews 10-11, the author of Hebrews encourages his readers to persevere and to live a life according to the choice that they made before when they accepted the mediatory role of Christ. This would inevitably lead to a lifestyle that leads to the seeking of peace with all people (Heb 12:14) (Stott 1998:138) and to love each other with a mutual kind of family love $(13: 1)$.

\subsection{The horizontal dimension}

Looking then at the disposition of the process of reconciliation according to Hebrews, the current status of believers is that they are standing in an already repaired (reconciled) relationship regarding their vertical dimension, that is, regarding their relationship with God. This status of the believers as described by $1^{\text {st }}$ Peter is seen as the 'elect of God', though they are 'strangers in the world', who were 'pre-destined and elected by God the Father' and who were 'being sanctified by the work of the Holy Spirit' (1 Pet 1:1-2). Also Jude describes them as those who were 'called by God the Father' and as those whom God 'loves and whom he protects through Jesus Christ' (Jude 2). They are dead to sin and live in obedience to the will of God (1 Pet 2:24). 
What are the implications of this repaired vertical relationship? What are the options facing the believers now regarding their interpersonal relationships on a horizontal level? Theoretically there are only two options:

(a)The first option is that they could merely ignore each other. They could portray a position as if they are unaware of their new status in Christ, or as if this vertical dimension is the only dimension and that mutual interpersonal relationships are non-existent. This attitude could either be passive and negative, or it could be an active attitude of aggression and rejection. Either way, this attitude will cause them to drift further apart from each other. By ignoring each other the divide will beome bigger and bigger.

(b)The second option is that they could look at each other and take notice of each other. By recognising and acknowledging their reconciled position in the presence of God (which is a confessionary act $)^{3}$, they become aware of their interpersonal broken relationships. Moved by God's reconciliation they will move closer to each other and enter into the process of reconciliation themselves.

\subsection{Expectations - according to James}

It is especially the Epistle of James that concentrates on the expectations for a sound and healthy relationship between each other on the horizontal level. A "christliche Lebenslehre" (Mußner 1975:51) is pictured here. Merely acknowledging and confessing a repaired relationship between God and humanity results only in an empty frame which is standing incompletely on the building site. Not only the vertical pillars, but also the horizontal beams are needed. Rows of stones being built horizontally next to each other and layer after layer on top of each other ensures an enclosure that will protect from the onslaught of nature's elements. James focuses on this dimension. He becomes uncomfortably practical in describing these horizontal relationships. Martin captures the gist of James' theology when he

3 Cf. Klein (1999:17) who points to three related aspects: Zeugnis (mart ur i a), Dienst (di a koni a) and Feier (l ei t our gi a). 
writes: “...to convince those who think they need only to profess their faith that such a merely professed faith is no faith at all, that it does not meet the deepest spiritual needs, nor does it result in salvation" (1982:30).

From a socio-historical point of view, the primary relationship that James is dealing with in his epistle is that between the rich and the poor in two areas of life: in the congregation (Ja 1:9-11 and 2:1-13) and on the farms on the outskirts of the towns where the rich landowners and poor farm workers lived (Ja 5:1-6). The relationship between these social classes was tense. People were judgmental and showed favouritism (Ja 2:1) which is sinful and an act of breaking the law (Ja 2:9). They discriminated against the poor (Ja 2:4), insulted and exploited them and took them to court (Ja 2:6). The rich hoarded wealth (Ja 5:3) and failed to pay wages to the workers who mowed their fields (Ja 5:4). They lived in luxury and self-indulgence (Ja 5:5). This created a division between these social groups. The result was that the rich and the poor believers did not act according to what they said they believed. Faith became an empty statement and not an act of mutual love towards each other. For James, therefore, the expectation of a reconciled relationship of a believer with God means that faith without works does not exist (Ja 2:14-26). In fact, action is the visible proof of faith (Ja 2:18). (For different textual interpretations, see Martin 1988: 86-89). There could be no talk of faith without action. Affluent believers, on the one hand, cannot merely talk to someone in need without acting in addressing also the physical needs of such a person (Ja 2:16). On the other hand, the caution expressed against the taming of the tongue (Ja 3:1-12; 4:11-12), against bitter envy and selfish ambition (Ja 3:14), against the fights and quarrels that were due because they wanted something that they could not get (Ja 4:1-2), and the call to be patient in suffering and to persevere (Ja 5:7-11) were probably all meant for the poorer believers. Berger (1995:186) already pointed out that the meaning of Jesus' death is absent in James in reference to reconciliation, sin, blood or the passion of Christ. Although the Christology might not be as advanced as elsewhere in the New Testament corpus, the focus tends to be here more on the interpersonal relationships of restored believers. 
That proper communication with each other proves to be a real expectation for James becomes clear from the section that deals with the taming of the tongue (Ja 3:1-12). So was also communication with God as becomes clear from the sections that deals with prayer (Ja 4:3; 5:13-18). In fact, the vice list in Ja 3:1-18 points to actions that corrupt the relationship of love which is to exist between Christians who are standing in a vertical relationship of reconciliation. The reality of a restored relationship with God will take shape in the praxis. Actions will be the evidence of the renewed status. Communication is a vitally important expectation of Christians who have been reconciled with God through Jesus Christ.

When bearing in mind the context and nature of this Epistle, it seems to end on a surprising note: Christians should take responsibility for each other and to actively bring back those who drift away. In doing this, they will save their fellows from death and will assist in causing the forgiveness of their sins (Ja 5:19-20) (Armerding 1932:195-201). This highlights the mediatory role that Christians can play in the process of reconciliation.

\subsection{Consequences - according to $1^{\text {st }}$ Peter}

The author of $1^{\text {st }}$ Peter presents a picture of a Christian who is reconciled with God. The consequences of that reconciliation are to be found in two areas. The first deals with their identity in Christ, their state of being, who they are. It relates to the present. The second deals with what they should strive to become. It explains what their behaviour should look like and, therefore, how they should behave in each other's company. It relates to the future. According to Elliott, "This letter is an exceptional example of how the 'good news of salvation' was set forth with regard to the social and religious conditions of the early Christians” (1982:62).

There are a number of images or metaphors being used in $1^{\text {st }}$ Peter with regard to the believers as an appeal that they should strive to live a holy life (1 Pt 1:15-16) and to be who they actually are. These include the following: 
- their faith is compared with gold that is purified by fire (1 Pt 1:7);

- the blood of Christ the Lamb redeemed them from an empty way of life (1 Pt 1:2,19);

- they should crave pure spiritual milk like newborn babies (1 Pt 2:2);

- Christ is the living stone (1 Pt 2:4) and they are living stones too (1 Pt 2:5);

- they are a spiritual house and should bring spiritual sacrifices (1 Pt 2:5) as they are a royal priesthood (1 Pt 2:9);

- Christ is the Shepherd and Protector of their lives (1 Pt 2:25).

Reformulated, this means that the faith of the believers of $1^{\text {st }}$ Peter is more precious than gold, that they are redeemed by the death of Christ, that they should strive to grow spiritually and that they are the building blocks of God's spiritual house. No wonder then that they should not conform to the evil desires they had when they lived in ignorance $(1 \mathrm{Pt}$ $1: 14)$ and to rid themselves of all malice and all deceit, hypocrisy, envy, and slander of every kind (1 Pt 2:1).

The vertically restored relationship has definite consequences for the horizontal relationships of Christians. Some of these consequences are being stated clearly by the author. One of the first relationships discussed is that of non-believers, or 'pagans'. The lifestyle of believers ought to be of such a nature that the non-believers may see their good deeds and glorify God (1 Pt 2:12) - “...die Christen mögen sich um einen guten Wandel bemühen” (Schelkle 1976:70). A behaviour that reflects that of a reconciled relationship with God will lead to good works, which, in turn, serve a mediatory purpose in the reaction of the non-believers to God. An interesting aspect here, is that the mere exemplary behaviour already has a powerful influence on those who observe it.

Then follows three more relationships, namely those with the authorities, within the working place and within the marriage. Regarding the authorities, it is known that Christian believers found it difficult to live in these times. They were actively persecuted and passively humiliated and marginalised. But it was expected from 
Christians in $1^{\text {st }}$ Peter not to talk negatively about the authorities. In doing so it results in them being persecuted even more. They should rather break this cycle (1 Pt 2:13-17). The early Christians were expected to show respect for all people (1 Pt 2:17). The same applies to a labour relationship (1 Pt 2:18-25) or a marriage relationship (1 Pt $3: 1-7)$. It is by means of exemplary behaviour that relationships can be restored as well. Women who are married to husbands who are not Christians could sway their husbands by merely being an example to them. Their behaviour, without even speaking a word, could lead to the restoration of their husband's relationship with God (1 Pt 3:1-2).

The mediatory example of Christ should be the model upon which they build their own lifestyle. Christ suffered, not because of what he did wrong, as he was without sin (1 Pt 2:22), but on our behalf (1 Pt 2:24-24; 3:18). That is why we are dead for sins and live for righteousness. Through his wounds we have been healed (1 Pt 2:24) (Similarly argued by Goppelt 1978:246; Carver 1930:323). This is $1^{\text {st }}$ Peter's description of the restored vertical relationship between God and humanity. Based on this reconciliation, Christians should learn to become mediators too. By tolerating their suffering for doing good they prove their faithfulness to God (1 Pt 2:19) and reflect the grace of God (1 Pt 2:20). They should understand their own suffering in the sense that they are not suffering for what they are doing wrong (being a murderer or thief or any kind of criminal, or even a meddler, according to $1 \mathrm{Pt} 4: 15$ ), but because they are Christians, carrying the name of Christ (1 Pt 4:16). As reconciled believers, they should be prepared to suffer for doing good (1 Pt 3:17) because their mediator, Christ himself, suffered too (1 Pt 4:12-19). They should actually rejoice in this suffering as this is the proof that they have God's Spirit (1 Pt 4:15).

In fact, faith and suffering are closely connected in $1^{\text {st }}$ Peter. It was already mentioned that their faith reaches another dimension through suffering - like gold that is purified by fire (1 Pt 1:6-7). It is through the mediatory role of Christ that Christians believe in God and therefore are directing, not only their faith, but also their hope on God (1 Pt 1:21). Because of the fact that they are reconciled (being purified by obeying the truth) - that is, being in a restored vertical relationship that they should love one another deeply, from the heart (1 Pt 1:22; 4:8) 
- that is, to also strive towards restored horizontal relationships.

Part of the consequences of the restored vertical relationship is that the believers will serve each other with their gifts. Each one should use whatever gift was received to serve others. By doing so they administer God's grace in its various forms (1 Pt 4:10). In administering these gifts, the role of a reconciled Christian believer takes the shape of a mediator - based on the example of Christ himself. The layers of bricks that are being built alongside and on top of each other find their orientation point and their support in the cornerstone. They are being built into the spiritual house.

\subsection{Dangers and Purpose - according to $2^{\text {nd }}$ Peter and Jude}

The close connection between $2^{\text {nd }}$ Peter and Jude has long been acknowledged. Both epistles emphasize particularly the danger of heresies that are doing the rounds. The behaviour of these false teachers within the context and circumstances of their time is being described in Jude 4-16 and in 2 Peter 2. The author of the latter concluded that "if they have escaped the corruption of the world by knowing our Lord and Saviour Jesus Christ and are again entangled in it and overcome, they are worse off at the end than they were at the beginning. It would have been better for them not to have known the way of righteousness, than to have known it and then to turn their backs on the sacred command that was passed on to them" (2 Pt 2:20-21). "Christian freedom”, comments Elliott regarding 2 Peter, "is escape from the defilements of the world's corruption through the knowledge of the world's Saviour" (1982:151).

The biggest danger facing Christians who are finding themselves in a restored vertical relationship, that is, in a reconciled relationship with God, is that their mutual and interactive behaviour is not conducive for, and does not reflect, the same reconciled state on a horizontal level. "This means that such emphasis is placed on the gracious forgiveness of sins by God that people assume that it does not matter what they actually do or how much they sin..." (Eybers 1975:117). This kind of behaviour does not restore and unite, but divide (Jud 19). The ingredients for the cement that should hold the bricks together in a spiritual building is found in 2 Peter 1:5-7: faith, goodness, knowledge, self-control, perseverance, godliness, brotherly 
kindness and love. These are the qualities that bind the bricks together, that are building living stones into the spiritual house, protecting it from all sorts of dangers and from the forces of nature. This leads, in turn, to the reminding of Christians about their purpose - being called and elected by God (2 Pt 1:3). A vertically restored relationship should thus inevitably lead to horizontally restored relationships. Not division but unification is the purpose. According to 2 Peter 1, God's divine power has given us everything we need for life and godliness ( $\mathrm{v} 3$ ), and he has given us his very great and precious promises (v 4). The purpose of a horizontally restored relationship is thus thoroughly rooted in the calling and election of Christians participating in the divine nature $(\mathrm{v}$ 4). The purpose and need for reconciliation between people is not to be found in a hunger for the claiming of power - either in resources or in personal status. Christians who are finding themselves in a reconciled relationship with God already have divine power and are sharing in the divine nature of God.

Reconciled believers should "build themselves up in their most holy faith" and should "keep themselves in God's love” (Jud 20-21). Bauckham (1983:112-113) pointed out in this regard that "Jude does not mean that each of his readers should build himself up... but that all should contribute to the spiritual growth of the whole community”.

\section{CONCLUSION}

A few aspects regarding reconciliation became clear during our engagement with the so-called General Epistles:

1. Although the technical terms as such were not found, the motif of reconciliation is present in these books. Different elements in this motif and a variety of images are pointing to the restoration of broken relationships.

2. There are two clear dimensions that can be distinguished in reconciliation. The first is a vertical dimension which describes the restored relationship between God and humanity. The second is a horizontal dimension between people themselves. The first leads to the second and the second is the result of the first. Deist (1997:20) says in this regard that forgiveness sets you free and heals relationships. 
3. The position of the cornerstone is vitally important in the building of this spiritual house. The mediatory role of Christ was crucial in the process of reconciliation between God and humanity. Based on the model of this mediatory role of Christ, Christians who are bearing his name ought to play a mediatory role too in the process of reconciliation on the horizontal level.

4. Christian behaviour seeks to unite, not to divide. A restored vertical relationship thus leads inevitably to very specific expectations and consequences regarding interpersonal relationships. In the words of Barclay (1958:106): "The very essence of Christianity is the restoration of a lost relationship" (1958:106).

5. Purpose driven reconciliation has its roots deeply planted in the calling and election of God. Christians are not driven by a hunger for earthly power, but are already in possession of Gods divine power.

6. There are definite dangers that threaten the process of reconciliation. In the times of $2^{\text {nd }}$ Peter and Jude the dangers might have been different from those facing $21^{\text {st }}$ century Christians.

The master design for reconciliation between people already exists. The building should just be erected. New beginnings should be made. Clean the field and the building stand! Set the cornerstone in place. Erect the vertical pillars. Lay the rows of bricks. Leave space for the door and windows. The best way to create the future is to invent it. Move beyond fear, pain and anger. Let us move beyond our own self-centred emotions. We should not dwell in the museum too long (which presents our history), nor in the library (which presents the archives for literature and manuals on reconciliation), but rather in the workshop, the garage or the temple (place of worship).

\section{Consulted literature}

Armerding, C 1932. "Is Any among You Afflicted?” A Study of James 5:13-20. Bibliotheca Sacra 95, 195-201.

Barclay, W 1958. Katallasein - The Word of Reconciliation, in: Barkley, W More New Testament Words. London: SCM Press.

Bauckham, R J 1983. Jude, 2 Peter. (Word Biblical Commentary 50). Waco: Word Books. 
Berger, K 1995. Theologiegeschichte des Urchristentums. Tübingen: Francke Verlag.

Carver, W O 1930. s.v. Atonement. ISBE I, Chicago: Howard-Severance Company, 321-324.

-, 1930. s v Propitiation. ISBE IV, Chicago: Howard-Severance Company, 2467.

Deist, F E 1997. Vergewe en Vergeet? Oor waarheid en versoening in Christelike perspektief. Pretoria: J L Van Schaik.

Elliott, J H 1982. 1-2 Peter/Jude. (Augsburg Commentary on the New Testament). Minneapolis: Augsburg Publishing House.

Eybers, I H 1975. Aspects of the background of the Letter of Jude. Neotestamentica 9, 113-123.

Goppelt, L 1978. Der Erste Petrusbrief. (KEK 12/1). Göttingen: Vandenhoeck \& Ruprecht.

Green, J B, McKnight, S \& Marshall, I H 1992. Dictionary of Jesus and the Gospels. Downers Grove, Ill.: InterVarsity Press.

Harrison, E F 1964. The Theology of the Epistle to the Hebrews. Bibliotheca Sacra 121, 333-339.

Hengel, M 1981. The Atonement. London: SCM Press.

King, M L 1988. Strength to Love. Glasgow: William Collins Sons \& Co Ltd.

Klein, C 1999. Wenn Rache der Vergebung weicht. Theologische Grundlagen einer Kultur der Versöhnung. Göttingen: Vandenhoeck \& Ruprecht.

Martin, R A 1982. James (Augsburg Commentary on the New Testament). Minneapolis: Augsburg Publishing House.

Martin, R P 1988. James (Word Biblical Commentary). Waco: Word Books.

M'Caig, A 1930. s.v. Reconcile, International Standard Bible Encyclopedia IV, 2536-2538. Chicago: Howard-Severance Company.

Mußner, F 1975. Der Jakobusbrief (HThKNT). Freiburg: Herder.

Schelkle, K H 1976. Die Petrusbriefe. Der Judasbrief (HThKNT). Freiburg: Herder.

Seifrid, M A 2004. s.v. Death of Christ III: Acts, Hebrews, General Epistles, Revelation, The IVP Dictionary of the New Testament. Leicester: InterVarsity Press, 292-310.

Seume, R H 1942. Divine Propitiation: Part 3. Bibliotheca Sacra 99, 469-485.

Steyn, G J 2002. The Vorlage of the Melchizedek phrases in Heb 7:1-4. Acta Patristica et Byzantina 13, 207-223. 
-, 2003. Addressing an angelomorphic christological myth in Hebrews? Hervormde Teologiese Studies 59(4), 1107-1128.

Stott, J R W 1998. Social Action. Grace Theological Journal (electronic edition). Garland, TX: Galaxie Software.

Tuckett, C M 1996. Atonement in the NT, in: Freedman, D N (ed), The Anchor Bible Dictionary. New York: Doubleday, 518-522.

Walvoord, J F 1962. The Person and Work of Christ. Part XII: Reconciliation. Bibliotheca Sacra 119, 291-301.

Williams, S K 1975. Jesus' Death as Saving Event. Missoula: Scholars Press. 